Катарина В. БЕГОВИЋ* Универзитет у Београду Филолошки факултет
Оригинални научни рад

Примљен: 25.12.2019.

Прихваћен: 12.02 .2020$.

\title{
ФРАЗЕОЛОШКИ МОДЕЛ 'ИНТЕНЗИФИКАТОР И КВАЛИФИКАТОР ЖИВ + ИМЕНИЦА' СА ЗНАЧЕЊЕМ ЉУДСКЕ ОСОБИНЕ
}

Предмет рада је продуктивни фразеолошки модел реализован у јединицама живи огањ (ватра), жива (цела једна, путујућа, ходајућа) енциклопедија (лексикон, књига), живи мртвац (леш), жива легенда и сл. Модел је на синтаксичком плану реализован именичком синтагмом са конгруентним атрибутом, а семантички припада тематској групи 'човек', са општим значењем 'човек је носилац особине изражене именицом у великој мери', чиме се конкретне фразеолошке јединице подводе под структурно-семантички стабилну фразеосхему у ширем смислу. Анализа одабраних фразеолошких јединица показује изразит структурно-семантички динамизам и аналошко уопштавање у формирању фразеосхеме без обзира на механизме фразеологизационог процеса и фразеолошки статус појединачних јединица. Придев жив у реализацијама одабраног модела добија улогу интензификатора и квалификатора фразеолошког значења (фразеологизми у ужем смислу) или лексичког значења (фразеологизми у ширем смислу). Неки од анализираних фразеологизама отварају питање универбизације фразеолошке структуре, као и питање фразеолошког калкирања.

Кључне речи: фразеолошка јединица, фразеологизам, фразеолошки модел, фразеосхема, придев жив, универбизација фразеолошке структуре, аналогија, синтаксичко-семантички динамизам.

\section{1. Предмет истраживања}

У раду се анализира део фразеолошког корпуса са компонентом жив у српском језику који се условно може подвести под исту фразеосхему. Ради се о образовањима типа живи огањ (ватра), жива (цела једна, путујућа, ходајућа) енциклопедија (лексикон, књига), жива легенда, живи мртваи (леш), живи очај, жива досада итд., која имају категоријално именичко значење и припадају тематској групи 'човек'. Фразеосхема представља реализацију

\footnotetext{
"katarina.v.begovic@gmail.com
} 
структурно-семантичког модела 'именичка синтагма са конгруентним атрибутом израженим придевом жив' са значењем 'човек је носилац особине изражене именицом у великој мери', па су тако овом фразеосхемом изражене различите људске физичке и психичке особине - 'бити много храбар (спретан, вредан, страствен)', 'бити много паметан', 'бити мршав до крајњих граница', 'бити много познат' и сл. ${ }^{1}$

Циљ рада није исцрпан опис свих појединачних фразеолошких јединица које се могу сврстати у описану фразеосхему (одабрани модел је врло продуктиван), већ представљање модела, историјско мапирање најстарије реализације датог модела и формирања фразеосхеме, увид у структурно-семантички динамизам заслужан за развијену фразеосхему, затим увид у фразеолошки статус ${ }^{2}$ јединица и механизме фразеологизационог процеса. Зато су представљени само они фразеологизми чијом се анализом наведено може одсликати на репрезентативан начин.

\section{2. Фразеолошки модел 'интензификатор и квалификатор жив + именица' са значењем људске особине}

\section{1. Реализаиија модела са фразеолошким значењем 'бити много храбар' и осталим сродним значењима}

2.1.1. Под значењем 16 одреднице ватра у РСАНУ наводе се значења: „а. веома вредан, жустар, хитар (на послу). [...] б. брз као муња, ватрен (за коња). [...] в. одважан, куражан, храбар (човек, јунак). [...] г. кочоперан. [...] д. веома привлачан, заносан." (s. v. ватра, РСАНУ). ${ }^{3}$ Ова метафоричка значења су међусобно повезана и наводе се и као фразеолошка значења синтагми живи огањ (ватра, жеравица) у ексцерпираној грађи. Међутим, историјски корпус упућује на фразеолошко значење 'срчан и храбар човек' старије од

\footnotetext{
${ }^{1}$ В. М. Мокијенко под фразеосхемом подразумева фразеолошке јединице које представљају реализацију јединственог структурно-семантичког модела. Фразеосхема настаје варирањем лексичких компонената саставница фразеологизма, при чему лексеме које подлежу варирању не морају бити синоними, већ могу припадати одговарајућој тематској групи. Међутим, „тематическая однородность, естественно, имеет свою фразеологическую специфику и должна пониматься более широко, чем простое вхождение в конкретную тематическую группу лексики" (Мокијенко 1989: 34). Ако се фразеосхема схвати као реализација фразеолошких јединица исте структуре и истог општег значења, закључује се да не морају само конкретне фразеолошке варијанте чинити фразеосхему, већ и различити структурно исти, а семантички сродни фразеологизми, који деле прототипични базни облик, тј. своде се на заједнички апстраховани структурно-семантички модел.

${ }^{2}$ У раду се, са ослонцем на традиционалну поделу С. И. Ожегова, разликују фразеологизми у ужем и у ширем смислу, и то према критеријуму семантичке реинтерпретације лексема саставница фразеолошке јединице: фразеологизам у ужем смислу је експресивна вишелексемна јединица чије се значење не може свести на збир значења компонената фразеологизма, а фразеологизам у ширем смислу је (експресивна) јединица чије се значење може свести на збир лексичких значења његових лексема саставница (уп. Мокијенко 1989, Мршевић Радовић 1987, Вуловић 2015 итд.).

${ }^{3}$ Слична значења наводе се и под тачком 10 одреднице огањ (s. v., РСАНУ)
} 
лексичког, што упућује на потенцијалну универбизацију фразеолошке структуре - у српском језику синтагма живи огањ (ватра) користи се да означи храбре ратнике, и то од 16 . века, што ову синтагму чини најстаријом реализацијом разматраног фразеолошког модела:

(1) „Prid ńim živi ogań Bošńani se vide. Krnarutić 8 a” $(1584)^{4}$ (s. v. ogań, PJA3У);

(2) „Tatarin je - vatra živa - preti mačem, pa doziva. Radićević (1880)” (s. v. vatra, PJA3У).

Потврде о лексемама огағ и ватра у датом значењу без придева интензификатора су млађе, што је очекивано с обзиром на то да је интензификатор жив стални епитет уз именице огањ и ватра у епској поезији, а то би могло упућивати на велику старину синтагматског значења, уп.:

(3) „Iz usta mu (t. j. końu) živi ogań sipa, a iz nosa modar plamen suče. 2, 140” (друга књига Вукових народних песама) (s. v. ogań, РЈАЗУ).

2.1.2. Овакви „ватрени” атрибути приписују се змајевима, коњима и јунацима у народној епици, а данас су у српском језику „ватрени” људи и коњи они склони брзим покретима, живахни, пуни снаге (s. v. vatra, Матешић 1982):

(4) „... znam, mladi ste, gotova živa vatra! Đalski 5, Građa”;

(5) „Kola lepa i laka: arnjevi novi, konji mali ali živa vatra... Sremac 3, Građa".

2.1.3. Синтагма живи огағ (ватра) развија и хронолошки најмлађе значење 'страствен човек', у којем се препознају две метафоре: СТРАСТ JE ВАТРА И ЧОВЕК ЈЕ САДРЖАТЕЉ ЗА ЕМОЦИЈУ.

Примери употребе из речника сведоче и о особини припадницаิ женског пола:

(1) „Bijaše živ oganj ta njegova kćerkica. Red.” (s. v. oganj, Матешић 1982),

а некад се у овом контексту наслућује и сексуална конотација - у ХФР (s. v. živa vatra) стоји „1. vrlo temperamentna osoba”, а примери сведоче (и) о сексуалној страсти:

(2) „Znao sam da je Imoćanka, te su cure ŽIVA VATRA. (Y);

(3) Gabriella je ŽIVA VATRA u potrazi za izazovima. U očima joj se vidi da je vrckava. Nema problema s tabuima i nadasve uživa u uzbuđenjima. (N)".

2.1.4. За разлику од осталих фразеолошких јединица које припадају описаној фразеосхеми, дијахронијски увид у полисемију синтагме жива ватра показује да се полисемантичка структура синтагме може пратити од псл. нивоа и да је у уској вези са полисемантичком структуром именичког центра синтагме. У вези са тим отвара се сложено питање фразеолошке полисемије, као и статус придева интензификатора у синтагми - да ли у дијахронијској

\footnotetext{
${ }^{4}$ Године у загради испред лексикографског навода су године конкретног извора коришћеног за израду речника.
} 
перспективи он представља обавезан или факултативан члан фразеолошке јединице; последично се у вези са тим отвара и питање универбизације фразеолошке структуре. Придев у функцији интензификатора и квалификатора ${ }^{5}$ на савременом плану представља факултативни члан синтагме у свим наведеним значењима. Не улазећи у анализу целовите полисемантичке структуре синтагме, истичемо да је најстарије међу наведеним сродним значењима, која одговарају датом структурно-семантичком моделу, синтагматско значење 'бити много храбар', из којег су се различитим перспективизацијама развила остала, хронолошки млађа значења. С обзиром на то, факултативност придева интензификатора може се у дијахронијској перспективи објаснити семантичком кондензацијом, тј. универбизацијом фразеолошке структуре (,die semantische Kondensation (resp. die Univerbierung)", Валтер/Мокијенко 2018: 332). Овај процес за последицу има факултативност придева у површинској структури фразеолошке јединице јер је именица у историјском процесу постала носилац фразеолошког значења. ${ }^{6}$

\section{2. Реализачија модела са фразеолошким значењем 'бити много паметан'}

2.2.1. Фразеологизам са значењем 'бити много паметан' остварује се у облику жива (ходајућа, путујућа, и(иј)ела једна) енцииклопедија (лексикон, књига) и посведочен је у различитим словенским језицима у различитим варијантама; овде наводимо примере употребе из Матешићевог речника (s. v. živ, Матешић 1982):

(1) ,... Faller je kao naš filolog Budmani, cijela jedna enciklopedija. Matoš 5, Građa";

(2) „Ona je svojim znanjem odavala da je živa enciklopedija. Red.”.

Придевске компоненте које се користе у лексичком варирању најчешће припадају тематској групи 'активност', тј. 'кретање', чиме се категорија 'неживо' експлицитно одваја од категорије 'живо': жив, путујући, ходајући; за овакво варирање знају и словенски и други европски језици у којима је фразеологизам посведочен.

\footnotetext{
${ }^{5}$ Да придев у анализираном примеру није само у функцији интензификатора показује лексичко варирање у структури фразеолошке јединице: жива се може заменити придевом права, што упућује и на квалификацију унутар тематске једнообразности лексема̂ чија је употреба последица фразеолошког динамизма. Придев жив је иначе склон делимичној десемантизацији и перспективизацијама и у другим контекстима (уп. примере жива истина, живи пример, живи доказ, живо злато и сл.).

6 За сада не треба искључити ни другу могућност реконструкције синтагме - придев у улози интензификатора и квалификатора уз одговарајуће значење именице (из ове перспективе говори се о фразеологизму у ширем смислу), мада историјска перспектива упућује пре на семантичку кондензацију фразеолошке структуре. О самој факултативности придева уз наведена метафоричка значења именицаิ огањ/ватра говори и стање на ширем словенском простору јер се значење живахне особе, страствене особе реализује (и) без придева интензификатора (за јсл. језике уп. s. v. ogenj, ССКЈ, Кебер 2015; s. v. огън, РБЕ; s. v. оган, ДРМЈ).
} 
2.2.2. Матешићев речник бележи још једну варијанту фразеологизма:

(3) „On vam je živa knjiga... V 1885, Građa” (s. v. živ, Матешић 1982).

У Матешићевом речнику је варијанта са компонентом књига наведена као посебна фразеолошка јединица, као и лексикон, међутим, у питању су фразеолошке варијанте:

1) све јединице имају исто значење;

2) центар синтагме увек чини нека од лексема која припада тематској групи 'књига' јер је књига уопште симбол знања; претпоставка је да варијанта са именичком компонентом кюига припада аутентичном српском (и словенском) корпусу, а да су варијанте са компонентом енщиклопедија и лексикон последица каснијег лексичког динамизма који подразумева лексичко позајмљивање, или пак последица правог фразеолошког калкирања, ${ }^{7}$ уп: фр. encyclopédie vivante (s. v., Ларус), енгл. walking encyclopedia (dictionary) (s. v., ЕД), нем. eine lebende Enzyklopädie (ein wandelndes Lexikon) (немачки информатори) ${ }^{8}$ итд.

Д. Мршевић-Радовић (2004: 97) анализирала је фразеолошке јединице са компонентом књига и показала следеће:

у српском језику [у процес фразеологизације, К. Б.] књига улази са значењем ,јеванђеље” [...], и са значењем „књига из које се учи читање и писање” (синоним - буквар). У првом значењу, књига којом се преноси духовно наслеђе „симбол је знања и мудрости”; у другом, реч је о књизи из које се стичу неопходна знања која одређују човеково место и положај у свету (уп. РС 1983).

С обзиром на важност књиге у значењу 'јеванђеље', порекло фразеолошке јединице са компонентом књига можда треба тражити у наслеђеној јудео-хришћанској традицији (у словенским језицима уопште); у том светлу, жива књига би се могла посматрати паралелно са живом (Божијом) речи и (живим) јеванђељем, и као таква представљала би примарну фразеолошку варијанту разматраног фразеологизма.

2.2.3. Анализирана јединица је прави фразеологизам који настаје глобалним метафоричким преносом. Као што се у енциклопедији или лексикону даје ошти приказ знања о свету, тако човек може бити толико образован,

\footnotetext{
${ }^{7}$ Као један од кључних проблема у фразеологији намеће се проблем фразеолошког калкирања. Њиме су се, међу другима, у словенској фразеологији бавили Н. И. Толстој (1995) и Х. Валтер и В. Мокијенко (2018). За сада је показано да изрази не морају бити нужно позајмљени ако се јављају у западноиндоевропским језицима, нити да морају бити нужно позајмљени ако се јављају широм словенског простора (што у најкраћем представља Толстојеве хипотезе). Као одлучујући аргумент понуђен је културолошки код. Ако је фразеолошка јединица део етнокултурног словенског бића, вероватно је прасловенска (било да је аутентична прасловенска или континуант ие. културног и језичког прамодела). Ако није, чињеница да је посведочена у западноиндоевропским језицима и на већем делу словенског простора обично се интерпретира као резултат калкирања.

${ }^{8}$ На основу усмено пренетих информација од Н. Вуловић, резултати мини-анкете коју су спровели студенти групе за лингвистику Универзитета у Келну, а која је обухватила говорнике од 20 до 60 година, показано је да фразеологизам eine lebende Enzyklopädie постоји углавном као део пасивног фразеолошког фонда. Старијим испитаницима фразеолошка јединица била је потпуно позната, а млађим генерацијама је прва асоцијација на овај фразеологизам био други, новији - ein wandelndes Lexikon.
} 
имати толико знања колико се може прочитати у енциклопедији. Семантичке компоненте које одликују књигу у процесу фразеологизације приписане су човеку, уз помоћ обавезног атрибута који осим улоге интензификатора има и улогу да недвосмислено упути на особине које одликују човека: 'жив', 'путујући', 'ходајући', дакле, покретан и активан, за разлику од књиге. Придев жив у фразеологизационом процесу постаје и квалификатор и интензификатор фразеолошког значења: енциклопедија је буквално жива - односи се на човека, а тај човек много зна (интензификација).

Оно што треба истаћи у даљем развоју фразеолошке јединице јесте чињеница да се у разговорном језику данас може чути нпр. Шта сам ја, енцииклопедија, па да морам све да знам... (и то не само у српском него и у другим словенским и несловенским језицима), што говори о процесу универбизације фразеолошке структуре и у овој јединици.

2.2.4. Специјализована фразеолошка значења 'много знати историју', 'много знати језик'

Западнојужнословенски језици знају још и за фразеологизам жива хрони$\kappa a(к р о н и к а)$ (s. v. živ, Матешић 1982; s. v. žív, ССКJ), а за наведени фразеологизам знају и западнословенски језици, в. нпр. пример из словачког корпуса:

(1) „Rád spomínal, bol živou kronikou. (A. Mat.)” (s. v. živý, CCJ).

Колико нам је познато, фразеолошка јединица се не јавља у романским и германским језицима, и вероватно је настала варирањем именичке компоненте тако да се уклопи у већ постојећи образац, само употребом лексеме која је индуктор ужег фразеолошког значења: 'много знати историју'. У бугарском језику не јавља се жива хроника, али је као паралела посведочен фразеологизам жива история (s. v. жив, РБЕ) са истим значењем. ${ }^{9}$

Све наведене реализације модела са овим значењем, као и посебне фразеолошке јединице настале варирањем почетне синтаксичко-семантичке структуре, потврде су фразеолошког динамизма и говоре о продуктивном структурно-семантичком моделу. ${ }^{10}$

\section{3. Реализација модела са фразеолошким значењем 'бити много мршав, изнемогао, болестан'}

2.3.1. Фразеолошка јединица живи мртваи јавља се у различитим варијантама широм словенског простора, а у српском језику посведочене су варијанте живи мртвац (леш) ${ }^{11}$, живе мошти (s. v. živ, Матешић 1982; s. v. živ, ХФР).

Фразеологизам је глобални метафорички и темељи се на нелогичном споју појмова који се искључују, тј. на оксиморону (Вуловић 2015: 143).

\footnotetext{
${ }^{9}$ У бугарском је забележена још једна фразеолошка јединица настала лексичким варирањем варирањем, жива граматика (s. v. жив, РБЕ).

${ }^{10} \mathrm{O}$ синтаксичко-семантичком динамизму фразеологизма в. Мршевић Радовић 1982.

${ }^{11}$ Живи леш је варијанта која се јавља у разговорном језику, а лексикографски извори је не бележе.
} 
Према подацима из белоруског Етимолошког фразеолошког речника, фразеолошка јединица живи труn је калк према француском cadavre vivant, уп. „Жывы труп. Відаць, калька з франц. м. (cadavre vivant). Вельмі слабы, хворы, блізкі да смерці чалавек" (s. v. труn, Лепешав 2004). С обзиром на то да је фразеологизам интернационалан, врло је могуће да је дошао из француског језика на словенски језички и културни простор.

2.3.2. Међутим, овде треба истаћи чињеницу релевантну за српски језик. Фразеологизам живи труи на српском простору није уобичајен (у овој варијанти јавља се по правилу у источнословенским и источнојужнословенским језицима), већ варијанта живи мртваи или живи леш. Тако је зато што у српском језику лексема труn ретко значи 'леш', већ углавном значи '(мртво) тело без главе'. С обзиром на то да је источнословенски труп буквални превод фр. cadavre, а мртваи (леш) не, може бити да се фразеологизам развио независно на српском говорном простору.

Секундарно значење именице мртваи јесте „слаба, изнурена, изнемогла, исцрпљена особа", уп. примере употребе:

(1) „Жена опет родила ... А да их видиш, не зна се ко је гори мртвац, она, или онај њен весели муж (Паун. С. 1, 435)" (s. v. мртваи, РСАНУ).

Живи мртвач се у РСАНУ под одредницом мртвац наводи као израз са придевом интензификатором, који појачава секундарно значење именице ,жив(и) у појачаном значењу: мртвац (2)”:

(2) „Зар сви нијесмо као живи мртваци и сухи и мршави и гладни (Ћор. C. 9, 251)".

На основу примера у РСАНУ не може се закључити да ли је старији лексемски спој или секундарно значење именице. ${ }^{12} \mathrm{C}$ обзиром на изнесене податке:

1) изгледа да синтагма живи мртваи (леш) у српском језику није калк;

2) живи мртвац могао је настати на два начина:

a) у јединици није дошло до правог фразеологизационог процеса, већ се придев у функцији интензификатора користи уз секундарно значење именице мртвац; међутим, тиме што се употребом придева постиже изразита експресивност, а синтагма добија статус оксиморона, приближава се фразеологизму у ужем смислу;

б) секундарно значење именице мртвац о болесном, изнуреном човеку могло је настати универбизацијом фразеолошке структуре (живи $\leftrightarrow$ мртвац $\rightarrow$ живи мртвац $\rightarrow$ живи $\left({ }_{\text {живи+ }}\right.$ мртввач $) \rightarrow(\text { живи })_{\text {живи+ }}$ мртввач $\rightarrow{ }_{\text {живи+ }}$ мртввац..$^{13}$

\footnotetext{
${ }^{12}$ РЈАЗУ не бележи метафоричко значење именице мртвац, нити фразеолошку јединицу живи мртвац.

${ }^{13}$ У прилог томе да је живи мртваи настао универбизацијом можда могу говорити паралелни подаци о фразеолошкој варијанти живи леш, јер леш нема секундарно значење изнурене особе, већ то значење остварује у фразеологизационом процесу (s. v. леш, РСАНУ; РМС). РМС под ознаком 1. б) са квалификатором фигуративно бележи пример: „Човек је постепено постајао
} 
Лексички динамизам синтагме живи мртваи у српском језику постиже се варирањем именичке компоненте (леш). Међутим, поред фразеолошких варијанти живи мртвац и живи леш, у српском и бугарском језику, заједно са источнословенским језицима, посведочен је и фразеологизам живе мош$m u$, јединица настала варирањем именичке компоненте из стилски маркираног, сакралног дискурса. Према Н. Вуловић (2015: 143) живе мошти су синонимна фразеолошка јединица са живим мртвацем (лешом). Међутим, јединице би се можда могле третирати као варијантне јер без обзира на порекло лексеме припадају истој тематској групи 'тело након смрти' (мртвац, леш, труп, кости, мошти).

Матешић (s. v. groblje) бележи још једну фразеолошку јединицу са истим значењем - живо (неопојано) гробље, са тим да треба имати у виду да је метафоричка транспозиција у фразеологизационом процесу овде заснована на метонимијском моделу ОБЈЕКАТ $\rightarrow$ МЕСТО НА КОМ СЕ ОБЈЕКАТ НАЛАЗИ. Ово ваља посебно нагласити јер дати пример показује моћ аналогије у формирању фразеосхеме и сведочи о различитим начинима постанка појединачних сродних фразеолошких јединица. ${ }^{14}$

2.4. На крају, поред анализираних јединица представљене фразеосхеме, посведочено је и фразеолошко значење 'бити много познат', изражено јединицом жива легенда. Фразеологизам није посведочен у савременим лексикографским изворима, нити је посведочено одговарајуће секундарно значење лексеме легенда да би се значење синтагме могло свести на значење именичког центра. С обзиром на то, јединица вероватно представља калк према енглеском језику, уп. „An extremely famous or notorious person, especially in a particular field, 'the man was a living legend"' (s. v. legend, ЕД).

Потврђено је и уже фразеолошко значење 'бити много лош у нечему', изражено јединицом живи очај (s. v. ос̌ај, ХФР), као и фразеологизам жива досада са значењем 'бити много досадан' (s. v. dosada, ХФР), затим мак. жива смеа (Велковска 2002: 61) и буг. жива разкрива (s. v. жив, РБЕ) са значењем 'бити много занимљив' итд., што потврђује продуктивност описаног фразеолошког модела и разгранатост дате фразеосхеме.

живи леш. Прод.”. Као једини пример употребе метафоричког значења лексеме леш дат је пример у синтагми живи леш.

${ }^{14}$ Последица структурно-семантичког динамизма јесте и чињеница да се овом моделу приближавају синтагме исте структуре и истог ширег значења које не пролазе кроз фразеологизациони процес, већ је, према увиду у лексикографске изворе, значење синтагме сведено на лексичко значење именице, а придев жив користи се као интензификатор и квалификатор именичког значења; таква је синтагма живи ђаво (враг) са значењем 'несташна, немирна, враголаста особа' (синтагма је посведочена у различитим словенским језицима, за јужнословенске в. s. v. жив, Оташевић 2012; s. v. živ, Матешић 1982; s. v. živ - ХФР; s. v. živ, ССКJ; s. v. жив, Нанова 2005; s. v. жив, PMJ). 


\section{3. Закључак}

Као опште запажање о анализираном моделу 'интензификатор (и квалификатор) жив + именица' са значењем људске особине намеће се изразит структурно-семантички динамизам, чија је последица развијена фразеосхема у ширем смислу. Описана фразеосхема је сложене хијерархијске структуре и дели се у подсхеме ужим фразеолошким значењима: 'бити много храбар' (и остала сродна значења), 'бити много паметан' (ову подсхему одликује изразита варијантност, а као последица лексичког варирања развија се и нова фразеолошка јединица са значењем 'много знати историју' у српском језику), затим 'бити много мршав, изнемогао, болестан' (јединице које припадају овој подсхеми такође одликује изразита варијантност), 'бити много познат', 'бити много лош у нечему', 'бити много досадан/занимљив' итд.

Према доступним подацима, најстарија реализација разматраног модела јесте синтагма живи огањ, са потврдом из 16. века, што значи да се фразеосхема развијала у периоду 16-20. век, а притом је модел и даље продуктиван. Све разматране јединице су експресивне и имају функцију секундарне номинације. Придев жив у фразеологизационом процесу постаје интензификатор и квалификатор фразеолошког значења (ту улогу придев код фразеологизама у ширем смислу добија у вези са лексичким значењем именице на коју се односи), а јединице имају могућност двоструке семантичке интерпретације. На крају, немају све реализације датог модела исти фразеолошки статус нити подлежу истим механизмима процеса фразеологизације, што потврђује значај аналогије и структурно-семантичког динамизма у ширењу фразеосхеме. Анализирани фразеологизми отварају питања универбизације фразеолошке структуре и фразеолошког калкирања.

\section{ИЗВОРИ}

Кебер 2011: J. Keber, Slovar slovenskih frazemov, Ljubljana: Založba ZRC, ZRC SAZU. Лепешав 2004: І. Я. Лепешаў, Этыммалагічны слоўнік фразеалагізмаў, Мінск: Беларуская Энцыклапедыя.

Матешић 1982: J. Matešić, Frazeološki rječnik hrvatskoga ili srpskog jezika, Zagreb: Školska knjiga.

Нанова 2005: А. Нанова, Фразеологичен синонимен речник на българския език, София: Издателство „Хейзъл”.

Оташевић 2012: Ђ. Оташевић, Фразеолошки речник српског језика, Нови Сад: Прометеј.

PJA3У 1880-1976: Rječnik hrvatskoga ili srpskoga jezika, I-XXIII, Zagreb: Jugoslavenska akademija znanosti i umjetnosti.

PМJ 1961-1966: Т. Димитровски, Бл. Корубин, Т. Стаматоски, Речник на македонскиот језик со српскохрватски толкувања I-III (редакција на Бл. Конески), Скопје: Институт на македонски јазик. 
PМС 1967-1976: Речник српскохрватскога књижевног језика, I-VI, Нови Сад: Матица српска.

РСАНУ 1959-: Речник српскохрватског књижевног и народног језика, Београд: САНУ.

ХФР 2014: A. Menac, Ž. Fink Arsovski, R. Venturin, Hrvatski frazeološki rječnik, Zagreb: Naklada Ljevak.

\section{ЕЛЕКТРОНСКИ ИЗВОРИ}

ЕД 2019: English Dictionary (Powered by Oxford), äînòóoiài ià https://www.lexico. com, последњи пут приступљено 17.10.2019.

Ларус 2019: Dictionnaire de français, доступан на https://www.larousse.fr, последњи пут приступљено 17.10.2019.

РБЕ 2001-: Речник на българския език, София: Академично издателство „Проф. Марин Дринов” / ЕT „Емас”, речник доступан на http://ibl.bas. bg, последњи пут приступљено 17.10.2019. http://ibl.bas.bg/rbe/lang/bg/

CCJ 1959-1968: Slovník slovenského jazyka I-VI, Bratislava: Vydavatel'stvo $\mathrm{SAV}$, доступан на http://slovniky.juls.savba.sk, последњи пут приступљено 17.10.2019.

CСКJ 2014: Slovar slovenskega knjižnega jezika, druga, dopolnjena in deloma prenovljena izdaja, Ljubljana: Inštitut za slovenski jezik Frana Ramovša ZRC SAZU, elektronska objava, spletna izdaja na http://fran.si, последњи пут приступљено 17.10.2019.

\section{ЛИТЕРАТУРА}

Валтер/Мокијенко 2018: H. Walter, V. Mokienko, Urslawische Phraseologie: Mythos oder Legende?, Deutsche Beiträge zum 16. Internationalen Slavistenkongress Belgrad 2018 (Herausgegeben von S. Kempgen, M. Wingender und L. Udolph), Wiesbaden: Harrassowitz Verlag, 331-340.

Велковска 2002: С. Велковска, Белешки за македонската фразеологија, Скопје: Институт за македонски јазик „Крсте Мисирков”.

Вуловић 2015: Н. Вуловић, Српска фразеологија и религија. Лингвокултуролошка истраживања, Београд: Институт за српски језик САНУ.

Мокијенко ${ }^{2}$ 1989: В. М. Мокиенко, Славянская фразеология, Москва: Высшая школа.

Мршевић Радовић 1982: Д. Мршевић-Радовић, Фразеолошка јединица и њен синтаксичко-семантички динамизам, Научни састанак слависта у Вукове дане, 11/1, 87-92.

Мршевић Радовић 1987: Д. Мршевић-Радовић, Фразеолошке глаголско-именичке синтагме у савременом српскохрватском језику, Београд: Филолошки факултет. 
Мршевић Радовић 2004: Д. Мршевић-Радовић, Фразеолошке јединице с компонентом књига, прилог српској лексикографији, Научни састанак слависта у Вукове дане, 32/1, 95-104.

Толстој 1995: Н. И. Толстој, Језик словенске културе, Ниш: Просвета.

\author{
Katarina V. Begović
}

\title{
PHRASEOLOGICAL MODEL 'INTENSIFIER AND QUALIFIER LIVING $(Z ̌ I V)+$ NOUN' WITH THE MEANING OF A HUMAN CHARACTERISTIC
}

\section{Summary}

The subject of this paper is a productive phraseological model realized in phraseological units of living fire (živa vatra), living encyclopedia (živa enciklopedija), living dead (živi mrtvac), living legend (živa legenda), etc. Syntactically, the model is realized by a noun syntagm with a congruent attribute, and semantically it belongs to the thematic group 'man', with the general meaning 'man is the bearer of a feature expressed by a noun to a large extent', which brings specific phraseological units sense.

The analysis of selected phraseological units shows a distinct structural-semantic dynamism and analogous generalization in the formation of the phraseological scheme, regardless of the individual mechanisms of the phraseological process. Individual phraseologisms open the question of the univerbization of phraseological structure, as well as the question of phraseological calcification.

Key words: phraseological unit, phraseological model, phraseoscheme, adjective living (živ), univerbization of phraseological structure, analogy, syntactic-semantic dynamism 